\title{
FORECAST ERROR OF VEHICLE VISITS TO A REPAIR SHOP IN QUANTIFYING THE INVENTORIES
}

\author{
BozIC, D.; TOMASIC, D. \& BABIC, D.
}

Abstract: Forecasts in logistic systems, including the aspect of inventories have the objective of reducing the effect of time delay in balancing the supply and demand. The forecast error effect can be considered, especially in case of inventories through financial losses and the level of service. The spare parts in automotive industry represent a big financial capital. It is precisely for that reason, as well as the reason of market affirmation of certain makes through the level of service of the center, that the significance of the policy of spare parts inventories management is constantly increasing. The paper shows the implementation of the ARIMA method of forecasting the vehicle visits to the repair shop, and in which way and how much the forecast error affects the capital invested in the spare parts inventories.

Key words: inventory management, demand forecast, forecast error
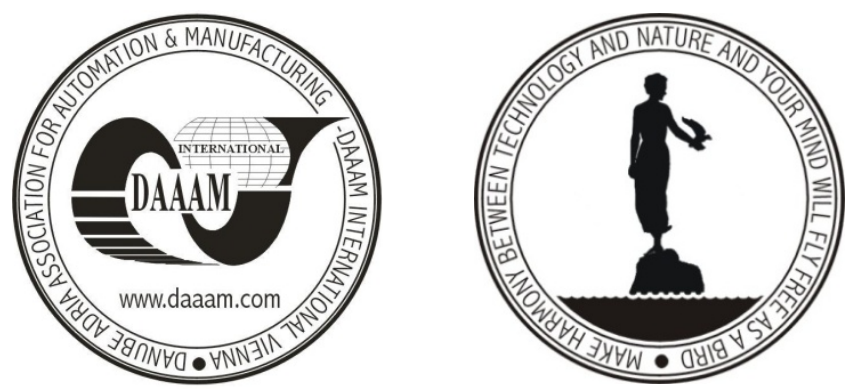

Authors' data: Prof. Bozic, $\mathrm{D}[\text { iana }]^{*}$; Tomasic, $\mathrm{D}[$ ubravko]**; Dr. Babic, $\mathrm{D}[$ arko]***, *University of Zagreb, Faculty of Transport and Traffic sciences, 2 Vrandučka 4, 10000, Zagreb, HR, **Auto Zubak, Josipovićeva 19, 10410, Velika Gorica, HR, ***Faculty of Transport and Traffic Sciences, Vukeliceva 4, 10000, Zagreb, HR, darko.babic@fpz.hr, diana.bozic@zg.t-com.hr, dubravko.tomasic@autozubak.hr

This Publication has to be referred as: Bozic, $\mathrm{D}$ [iana]; Tomasic, $\mathrm{D}$ [ubravko] \& Babic, D[arko] (2008). Forecast Error of Vehicle Visits to a Repair Shop in Quantifying the Inventories, Chapter 12 in DAAAM International Scientific Book 2008, pp. 137-146, B. Katalinic (Ed.), Published by DAAAM International, ISBN 978-3-901509-66-7, ISSN 1726-9687, Vienna, Austria

DOI:10.2507/daaam.scibook.2008.12 